\title{
FEATURE
}

\section{Soil science beyond COVID-19}

\author{
Rattan Lal
}

$\mathrm{T}$ he fast-moving coronavirus disease 2019 (COVID-19) pandemic engulfed the world within four months from December to March of 2020, with long-lasting impacts on social, economic, political, educational, and scientific programs. It exacerbated risks of food and nutritional insecurity for a large segment of society, and threats of disruption in the food supply chain may be aggravated by climate change, soil degradation, and the flood/drought syndrome. Ensuring adequate access to nutritious food is a daunting challenge even in developed/ scientifically advanced countries, and is a sheer tragedy in poor nations.

The sudden collapse caused by COVID-19 indicates fragility of humanity even to a microscopic foe. Cruel as it may seem, COVID-19 has accomplished what COP21 (the 2015 United Nations Climate Change Conference of Parties) and other initiatives could not. Atmospheric levels of carbon dioxide $\left(\mathrm{CO}_{2}\right)$ have not risen during March and April of 2020 (Storrow 2020; Flis 2020) because of the closure of the industry and travel restrictions. Even one month of lockdown has made the water of the Ganges River drinkable, air in cities like New Delhi and Beijing purer, and skies bluer than seen in decades (Biswas 2020). Historically, there is also strong evidence that a significant human depopulation (i.e., $\sim 10$ million) can create a cooling effect (Ruddiman and Carmichael 2006). Reduction in population of the Americas from 60.5 million by the end of the fifteenth century, using 1.04 ha $(2.6 \mathrm{ac})$ per capita of land, to merely 4.5 million by 1600 led to reforestation of $5.58 \times 10^{7}$ ha $\left(1.383 \times 10^{8} \mathrm{ac}\right)$ with uptake of $7.4 \times 10^{9}$ $\mathrm{t}\left(8.2 \times 10^{9} \mathrm{tn}\right)$ of carbon $(\mathrm{C})$ and decline in $\mathrm{CO}_{2}$ concentration by $7 \mathrm{ppm}$ (Koch et al. 2019; Ahn et al. 2012; McFarling et al. 2006). The objective of this discussion is to highlight some lessons that can be learned from flattening the COVID-19 curve by the lockdown that humanity can use in flattening the Keeling Curve through adoption of restorative land use, sustainable management of soil and water, and setting aside some land for nature.

\section{ANTHROPOGENIC ACTIVITIES AND COVID-19}

The COVID-19 pandemic may be a symptom of the increasing interaction between humans and the animal kingdom. Habitat has been altered by deforestation, in-field voluntary and intentional burning, excessive plowing and inundation by irrigation, indiscriminate use of chemicals, inappropriate use of natural resources, and of course, addiction to fossil fuel. Largescale conversion of natural ecosystems to managed landscapes, necessitated by the insatiable demands of a growing and increasingly affluent human population, has exacerbated interactions between humans and other animals. Increase in intensity and frequency of pandemics since the onset of twentieth century, of which COVID-19 is just one unfortunate event, indicates progressive increase in intensity and severity of such interactions, which are being aggravated by the anthropogenic climate change. The schematic in figure 1 depicts the onset of some overlapping vicious cycles, which are set in motion by ad-hoc deforestation, land misuse, and soil mismanagement. The ever-growing need for more deforestation leads to adverse effects on human wellbeing, health of the planet, and vicious pandemics. Encroachment of humanity on habitat, with adverse impacts on planetary processes, also aggravates the poverty-hunger-malnutrition-political unrest nexus.

Land degradation, characterized by decline in quality of soil, water, air, and biodiversity, affects 3.2 billion people or $40 \%$ of the world population in 2020 (IPBES 2019). Global loss of topsoil because of unsustainable agricultural practices, estimated at $2 \times 10^{9} \mathrm{t} \mathrm{y}^{-1}\left(26.5 \times 10^{9} \mathrm{tn} \mathrm{yr}^{-1}\right)$, reduced GDP by $10 \%$ and aggravated infectious diseases like Ebola and Marbug virus
(IPBES 2019). In terms of the geopolitical ramifications, land degradation is responsible for soil refugees, internal displacement, and political unrest (figure 1). The number of soil refugees may be 50 to 700 million by 2050 in West and South Asia, and subSaharan Africa. It is prudent, therefore, that agroecosystems for food production are kept within the bounds of environmental health (Springmann et al. 2018).

While calls by the scientific community and civic societies to reduce emissions have been ignored, lockdown forced upon humanity by COVID-19 may cut global emissions by $5 \%$ in 2020 and reduce atmospheric $\mathrm{CO}_{2}$ concentration by $1 \mathrm{ppm}$ (Komanoff and Ketcham 2020). However, reduction by $7.6 \%$ annually is needed between 2020 and 2030 to limit global warming to $1.5^{\circ} \mathrm{C}\left(2.7^{\circ} \mathrm{F}\right)$ (UNEP 2019). It is hoped that humanity will voluntarily bring about the required reductions in emissions before Mother Nature intervenes even more strongly.

\section{LESSONS LEARNED AND STRATEGIES FOR THE FUTURE}

The lockdown has strong scientific implications to conducting field research in soil science that begins in spring and includes soil sampling for determining the baseline properties prior to crop establishment, measuring the flux of greenhouse gases in relation to soil warming, evaluating surface runoff by snowmelt and spring rains, determining sediment and nutrient transport into aquatic ecosystems, monitoring trafficability and strength properties with soil, etc. The entire season of data collection for spring/summer 2020 may be lost to the necessity of flattening the COVID19 curve.

While the continuity in science matters, extra time available can be used for initiating and strengthening scientific net-

Rattan Lal is a distinguished university professor of soil science and is the director of the Carbon Management and Sequestration Center, The Ohio State University, Columbus, Ohio.

Received April 8, 2020; Published online April 25, 2020. 


\section{Figure 1}

Interconnected vicious cycles leading to degradation of soil, plant, animal, human, and environmental health caused by land misuse and soil mismanagement.

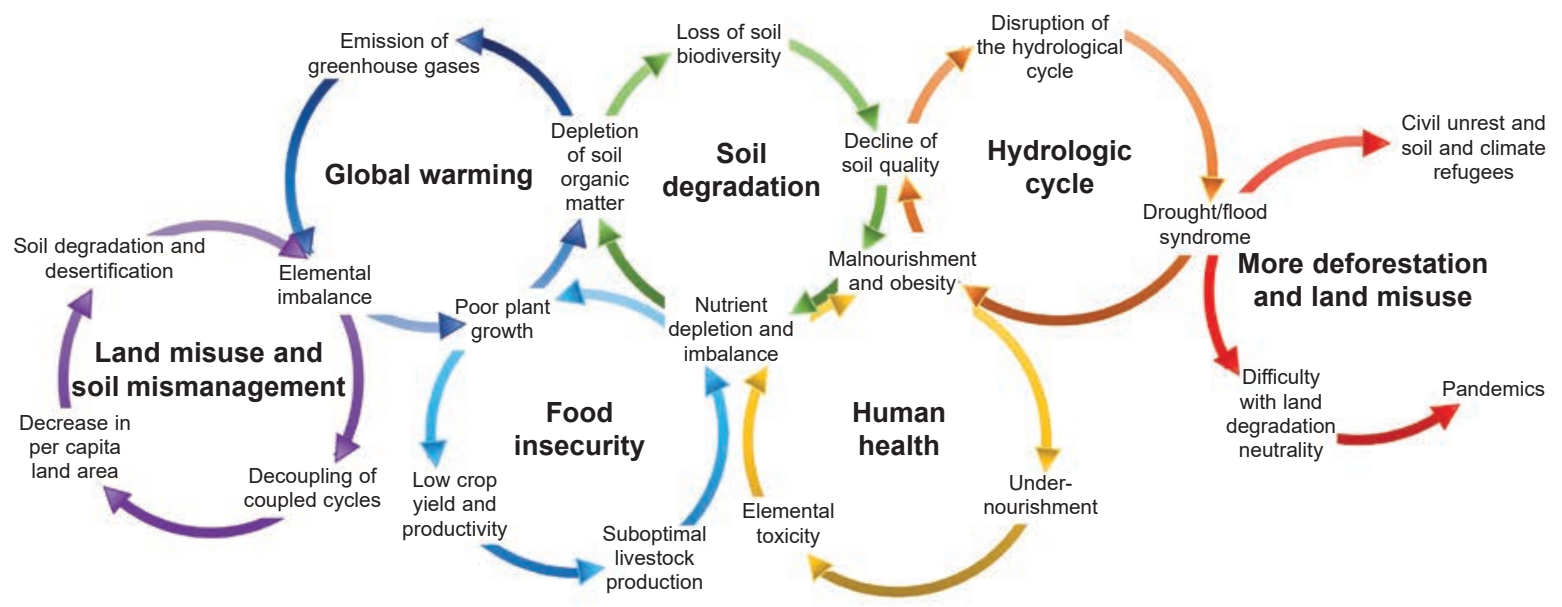

Anthropogenically Driven Soil and Environmental Degradation and Its Impact on Human Health

works through teleconferences and virtual workshops, tabulating and synthesizing the data from prior field and laboratory studies, writing journal articles or book chapters, and reflecting and contextualizing where the soil science has been and where it should be for effectively addressing the present and emerging challenges facing humanity and the planet Earth. Specifically, the soil science community must position itself to effectively compete for the ever-dwindling research dollars necessary to document that degradation of soil quality sets in motion interconnected vicious cycles with adverse effects on environmental and human health (figure 1). Therefore, this is the time to identify the entry point(s) to effectively break the overlapping vicious cycles.

Global agriculture is among the greatest success stories since the 1960s, as is documented by the quantum jump in agronomic yield and productivity. Despite the success, there were 820 million undernourished and almost 2 billion malnourished people globally even before the COVID-19 pandemic. Therefore, urgent action must be taken to protect the vulnerable population by ensuring that the food protection and supply chains are operational and secure. Protecting farmers against the adverse effects of the lockdown is essential to strengthening the resilience of the agricultural industry. With sustainable soil and agriculture management at the forefront of global issues, it is important to have a scientifically credible plan that is understandable and relatable for policymakers. This is the time for the scientific institutions to reflect, rethink, and revisit what needs to be done when the

shutdown is lifted. Analogous to developing a vaccine against COVID-19, it is also essential to develop an inoculation against the mindset about the importance of soil protection, restoration, and conservation. Maintaining soil quality and functionality is critical to advancing Sustainable Development Goals (SDGs) of the United

\section{Figure 2}

Importance of soil quality and functionality to Sustainable Development Goals (SDGs) of the United Nations.

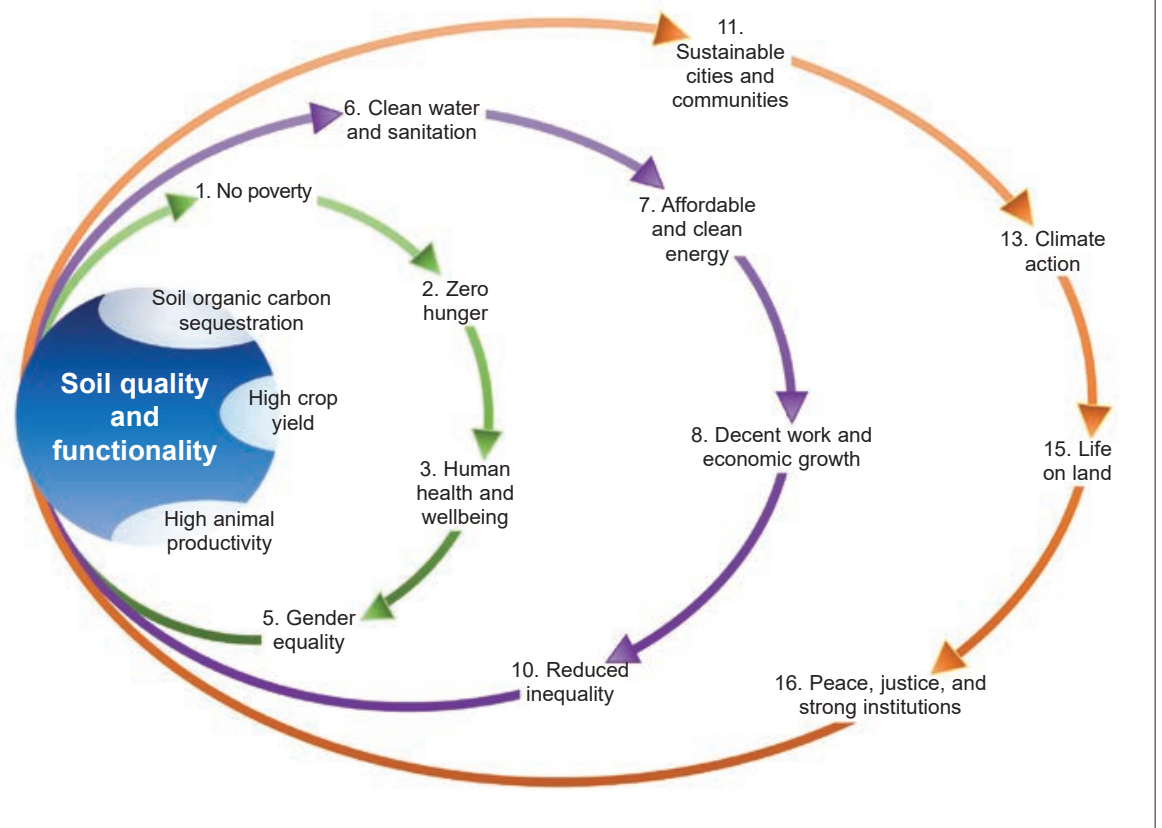


Nations, especially SDGs 2 (End Hunger), 3 (Human Health and Wellbeing), and 13 (Climate Action; figure 2), all of which are interconnected (Di Marco et al. 2020) and severely affected by the COVID pandemic.

The unfortunate and bitter truth about the loss of life and human suffering caused by the COVID-19 pandemic teaches humanity a lesson that unless it mends its ways, nature will do in its own ways what should have been done by us. It also teaches us that, with removal of the current lockdown, a business as usual approach is not acceptable. These pandemics, caused by increasing interactions of humanity with the animal kingdom, can be reduced by returning some land back to nature. Thus, there must be a paradigm shift in our values, lifestyles, and thinking. Indeed, the rate of global warming can be kept within a $1.5^{\circ} \mathrm{C}\left(2.7^{\circ} \mathrm{F}\right)$ limit by reducing our consumption; finding non-C fuel sources; returning some land back to nature for afforestation; using land and water judiciously; and never ever taking food, water, soil, and natural resources for granted. It is important that humanity takes from nature only as much as is needed, and no more.

\section{CONCLUSION}

The tragedy of COVID-19 pandemic has once again indicated the need for protecting, healing, restoring, and sustaining the wounded skin of the planet-the fragile soil. Through judicious management, reducing waste of food and losses of resources (soil, water, nutrients), some land must be set aside and returned back to nature for enhancing and restoring planetary processes.

The COVID-19 crisis necessitates implementation of the "One Health "strategy: health of soil, plants, animals, people, and environment is one and indivisible. Thus, formulation of a Soil Quality Act will support the existing Water Quality Act (1972) and Air Quality Act (1967), while also strengthening the environmental trinity: soil, water, and air. One of the lessons learned is that we can reduce emissions voluntarily by changing our values, lifestyle, and business as usual before Mother Nature does it for us.

\section{REFERENCES}

Ahn, J., E.J. Brook, J. Mitchell, J. Rosen, J.R McConnell, K. Taylor, D. Etheridge, and M. Rubino. 2012. Atmospheric $\mathrm{CO}_{2}$ over the last 1000 years: A high resolution record from the West Antarctic Ice Sheet (WAIS) Divide ice core. Global Biogeochemical Cycles 26(2):1-11.

Biswas, S. 2020. India Coronavirus: Can the COVID19 lockdown spark a clean air movement? BBC News, April 21, 2020. https://www.bbc.co,/ news/world-asia-india52313972.

Di Marco, M., M.L. Baker, P. Daszuk., P. De Barro, E.A. Eskew, C.M. Godde, T.D. Harwood, M. Herraro, A.J. Haskins, E. Johnson, W.B. Karesh, C. Machalaba, J.N. Garcia, D. Paini, R. Pirzi, M.S. Smith, C. Zambrana, D. Paini, R. Pirzi, M.S. Smith, C. Zambrana-Torreliio, and S. Ferrier. 2020. Sustainable development must account for pandemic risks. Proceedings of the National Academy of Sciences 117(8):3888-3892. https:// doi.org/10.1073/pnas.2001655117.

Flis, A. 2020. COVID-19 versus climate. Global $\mathrm{CO}_{2}$ levels have temporarily stopped rising, likely due to the industry slowdown as the world battles the new Corona virus. Global Weather, March 22, 2020. https:// www.severe-weather.eu/global-weather/ covid-19-global-co2-slowdown-climate-fa/.

IPBES (Intergovernmental Science-Policy Platform on Biodiversity and Ecosystem Services). 2019. The Global Assessment Report on Biodiversity and Ecosystem Services. https://ipbes.net/ global-assessment.

Koch, A., C. Brierly, M.M. Maslin and S.L. Lewis. 2019. Earth system impacts of the European arrival in America after 1492. Quarternary Science Reviews 207:13-36.

Komanoff, C., and C. Ketcham. 2020. What the Coronavirus pandemic can teach us about the climate emergency. The Intercept, April 4, 2020. https://theintercept.com/2020/04/04/coronavirus-pandemic-climate-change-co2-emissions/.

MacFarling, M., D. Etheridge, C. Trudinger, P. Steele, R. Langenfields, T. van Ommen, A. Smith, and J. Elkins. 2006. Low dome $\mathrm{CO}_{2}$, $\mathrm{CH}_{4}$ and $\mathrm{N}_{2} \mathrm{O}$ ice core records extended to 2000 year BP. Geophysical Research Letters 33:2000-2003.

Ruddiman, W.F., and A.G. Carmichael. 2006. Preindustrial depopulation, atmospheric carbon dioxide and global climate. Interaction between global change and human health. Scripta Varia 106.Vatican City: Pontifical Academy of Sciences. http://www.pas.va/content/dam/accademia/ pdf/sv106/sv106-ruddiman.pdf.
Springmann, M., M. Clark, D. Mason-D’Croz, K. Wiebe, B. Bodirsky, L. Lassaletta, W. de Vries, S.J. Vermeulen, M. Herrero, K.M. Carlson, M. Jonell, M. Troell, F. DeClerck, L.J. Gordon, R. Zurayk, P. Scarborough, M. Rayner, B. Loken, J. Franzo, H. Charles, J. Godfay, D. Tilman, J. Rockstrom, and W. Willett. 2018. Options for keeping the food system within environmental limits. Nature 562:519-525.

Storrow, B. 2020. Coronavirus is reducing $\mathrm{CO}_{2}$ : Why that is worrisome. E\&E News, April, 17, 2020.

UNEP (UN Environment Program). 2019. Emission Gap Report 2019. Global Progress Report on Climate Action. Nairobi, Kenya: United Nations Environment Program. 